\title{
Re-Design Jembatan THP dengan Sistem Box Girder Segmental
}

\author{
Jaka Propika ${ }^{*}$, Yanisfa Septiarsilia ${ }^{1}$ \\ ${ }^{1}$ Program Studi Teknik Sipil, Fakultas Teknik Sipil dan Perencanaan, Institut Teknologi Adhi Tama Surabaya \\ Email: *jakapropika@itats.ac.id
}

\begin{abstract}
Surabaya Bridge is commonly known by Surabaya people as THP Kenjeran Bridge. It was built above the sea or Kenjeran Beach for connecting Jl, Raya Pantai Lama (North Side) and Jl. Sukolilo Lor (South Side). Since it is a new bridge and becomes the icon of Surabaya City, many visitors from other places visit it. It was designed by using precast concrete structure in which I-Girder beam became the main girder, Pier Head as the girder pedestal, concrete pillar as the buffer, and foundation of pilling for supporting the top structure, of the bridge. As the bridge span is not too long, only 32 meters and requires many pillars, then the concrete needed by Surabaya Bridge becomes big and less efficient. For this reason, the researcher redesigned the bridge by modifying the bridge with box girder segmental system having span 48 meters for optimizing the total pier heads and pillars so as to be more efficient. This research was begun by collecting data of plans and literature through journals, reference books, and other sources. In this context, the researcher referred to SNI 1725-2016, SNI 2833-2016, and RSNI T-02-2005 which were specifically intended for planning the structure of bridge. The final results of this research were the shape and dimension of box girder cross section by 3,2 meter in height 16 meter in width, total prestress 18 tendons with 24 strands for each, and reduction total pear from 7 to 5 with the same concrete volume like the previous one.
\end{abstract}

Keywords: bridge, box girder, redesign

\begin{abstract}
Abstrak
Jembatan Surabaya atau yang lebih dikenal oleh warga Surabaya dengan jembatan THP Kenjeran, dibangun diatas laut atau pantai kenjeran dengan menghubungkan Jl. Raya Pantai Lama (sisi utara) dengan J1. Sukolilo Lor (sisi selatan). Merupakan jembatan baru dan menjadi ikonik di Kota Surabaya, sehingga banyak didatangi pengunjung dari berbagai tempat. Didesain menggunakan struktur beton pratekan, dimana balok I-Girder menjadi gelagar utama, Pier Head sebagai tumpuan perletakan gelagar, pilar beton sebagai penyangga, dan tentunya pondasi tiang pancang sebagai pendukung struktur atas jembatan. Karena dengan bentang jembatan yang tidak panjang, yaitu 32 meter, dan membutuhkan banyak pilar, sehingga volume beton yang diperlukan untuk membangun Jembatan Surabaya menjadi besar dan kurang efisien. Maka penulis merencanakan penelitian ulang dengan memodifikasi jembatan menjadi sistem box girder segmental dengan bentang 48 meter guna mengoptimasi jumlah pier head dan pilar, dan diharapkan menjadi lebih efisien. Penelitian ini dimulai dengan pengumpulan data - data perencanaan dan literatur yang diperlukan seperti jurnal, buku referensi, dan sumber lainnya. Dalam penelitian ini akan mengacu pada SNI 1725-2016, SNI 2833-2016, dan RSNI T-02-2005 yang dikhususkan untuk merencanakan struktur jembatan. Hasil akhir dari penelitian ini adalah mendapatkan bentuk dan dimensi penampang box girder dengan tinggi 3,2 meter dan lebar 16 meter, jumlah tendon prtegang 18 tendon dengan masing-masing tendon memiliki 24 strand, dan jumlah pilar berkurang dari 7 pilar menjadi 5 pilar dengan jumlah atau kuantiti volume beton yang sama seperti perencanaan sebelumnya.
\end{abstract}

Kata Kunci: jembatan, box girder, redesign 


\section{Pendahuluan}

Transportasi dan ekonomi adalah dua hal yang saling berkaitan satu sama lain. Terhambatnya kegiatan transportasi tentu akan berdampak pada menurunnya pendapatan secara ekonomi. Begitu pula sebaliknya, maka dari itu perlu adanya kesinambungan antara kedua hal ini sehingga pertumbuhan ekonomi dapat meningkat[1]. Jembatan Surabaya atau biasa dikenal dengan Jembatan THP (Taman Hiburan Pantai) Kenjeran merupakan suatu objek wisata sekaligus jalan akses yang menghubungkan antara Jalan Raya Pantai Lama dengan Jalan Sukolilo Lor Kota Surabaya. Dibangun pada tahun 2015, memiliki dua lajur satu arah menuju ke arah timur. Jembatan Surabaya juga merupakan icon wisata Kota Surabaya terbaru yang terletak pada kawasan pantai kenjeran, dimana harapan dari wali kota Surabaya kawasan pantai kenjeran tidak hanya sebagai tempat wisata biasa namun menjadi salah satu ikon wisata Kota Surabaya.

Seiring dengan makin berkembangnya teknologi maka konstruksi jembatan harus direncanakan sesuai dengan tuntutan transportasi baik dari segi kenyamanan, keamanan, maupun keindahan. Kemampuan dan ketahanan sebuah jembatan dipengaruhi oleh jenis dan bentuk penampang dari box girder[2]. Pembuatan bentuk boks baja dari pelat dengan metode tekuk dapat meminimalisasi jumlah sambungan, khususnya sambungan las. Sambungan las perlu menjadi perhatian khusus dalam konstruksi jembatan untuk jalan raya karena akan menjadi titik lemah untuk kondisi beban lelah / fatigue akibat akumulasi efek beban lalu lintas yang berulang-ulang[3].

Struktur jembatan menggunakan sistem beton prategang I-Girder, dimana dengan sistem ini membutuhkan banyak pilar (pier) sebagai tumpuan balok I-Girder pada bentang 192 meter dengan masing-masing jarak antar pilar 32 meter. Menyebabkan terlalu banyak penggunaan pilar pada bentang panjang sehingga memperbesar volume beton untuk konstruksi pilar jembatan dan memperbanyak jumlah titik tiang pancang pancang yang digunakan, hal ini merupakan kekuarangan sistem beton prategang I-Girder dalam segi volume pekerjaan. Konstruksi secara segmen lebih disukai pada jembatan karena berbagai alasan. Satu keuntungan dari metode ini mengurangi kesulitan pelaksanaan konvensional. Sebagian besar pekerjaan dilakukan dengan metode pracetak dan prosesnya bisa dimulai bersamaan dengan pekerjaan pondasi. Jembatan lurus atau melengkung dapat dibangun tanpa ada kesulitan, walaupun di medan yang sulit[4].

Dari permasalahan di atas maka perlu dilakukan remodeling struktur jembatan menjadi sistem beton prategang box girder segmental. Tipe box girder digunakan untuk jembatan bentang panjang. Desain box girder lebih menguntungkan untuk bentang menerus dengan panjang bentang lebih dari 100 $\mathrm{m}[5]$. Mengganti balok prategang I-Girder dengan box girder segmental, bentang pada jemabtan sepanjang 192 meter terbagi menjadi empat bentang, masing-masing bentang 48 meter dengan dua pilar di antara bentang, dengan kata lain jembatan dengan sistem prategang box girder ini mempunyai 5 tumpuan.

\section{Metode}

\subsection{Data Perencanaan}

Data-data perencanaan diperoleh dari PT. Surya Cahaya Utama Conulstant sebagai konnsultan perencana dalam pekerjaan DED Jembatan Surabaya (THP Kenjeran), Kota Surabaya, Jawa Timur. Jembatan Surabaya (THP Kenjeran) ini dimodifikasi ulang (remodeling) memakai box girder pratekan. Adapun data-data yang digunakan dalam perencanaan jembatan tersebut adalah sebagai berikut :

Panjang bentang jembatan

Lebar jembatan dan rencana jalan

Lebar trotoar

Lantai kendaraan beton bertulang

Gelagar utama

Mutu beton

Mutu baja

Mutu tendon
: $192 \mathrm{~m}$, terbagi menjadi 3 bentang

: $16 \mathrm{~m}, 10 \mathrm{~m}$.

: $2 \times 3 \mathrm{~m}$.

:2 lajur1 arah@5m.

: box girder segemental.

: K-750 (fc' $60 \mathrm{MPa})$.

: fy 420 , dan fy 280

: ASTM A416-85 Grade 270 


\subsection{Preliminary Design}

Total panjang Jembatan Surabaya (THP Kenjeran) yang diremodeling menjadi box girder segmental adalah 192 meter, dibagi menjadi 4 bentang, dengan masing-masing bentang 48 meter.

Tipe segmen dan panjang segmen box gider

Untuk segmental dalam potongan memanjang dengan panjang 192 meter, terbagi menjadi 5 tumpuan seperti pada gambar dibawah ini :

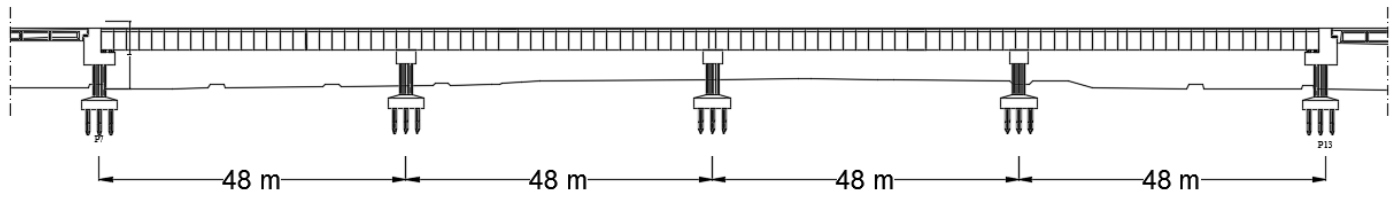

Gambar 1. Potongan Memanjang Box Girder Segmental

Sedangkan untuk segmental dalam potongan melintang dengan lebar rencana jalan 16 meter, terbagi menjadi 2 segmen box girder seperti gambar dibawah ini:

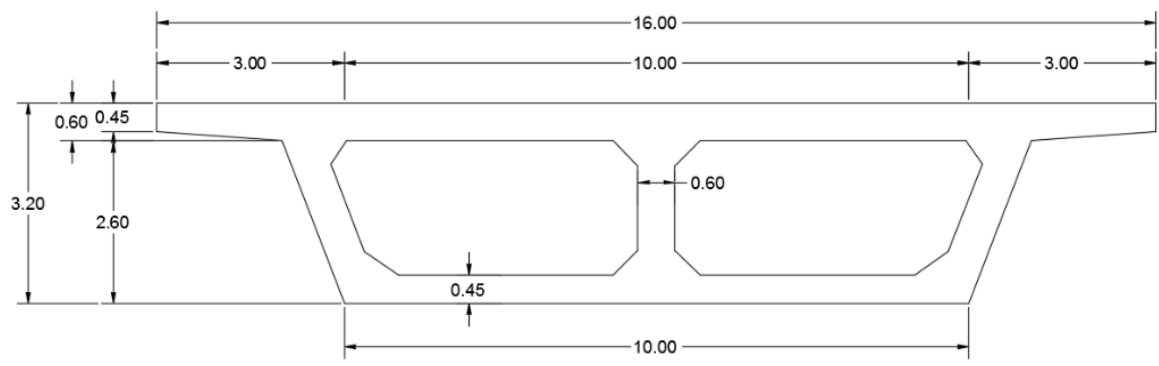

Gambar 2. Potongan Melintang Box Girder Segmental

\subsection{Menentukan Dimensi Box Girder}

Menentukan dimensi box girder menggunakan tafsiran untuk pra rencana desain segmental box girder.

Tafsiran Tinggi Box Girder

Ketebalan Minimum Web Box Girder

Ketebalan Minimum Top Flange Box Girder

Ketebalan Minimum Bottom Flange Box Girder

\subsection{Menentukan Dimensi Box Girder}

Beton

Kuat tekan beton prategang $\left(\mathrm{fc}^{\prime}\right)=60 \mathrm{MPa}$.

Kuat tekan beton untuk struktur sekunder ( $\left.\mathrm{fc}^{\prime}\right)=35 \mathrm{MPa}$.

Baja

Mutu baja yang digunakan untuk penulangan box girder adalah baja mutu

$(\mathrm{fy})=420 \mathrm{MPa}$.

Mutu baja yang digunakan untuk penulangan struktur sekunder adalah baja mutu (fy) $=280 \mathrm{MPa}$.

Dalam perencanaan ini jenis kabel dan angkur yang digunakan adalah ASTM A416-74 Grade 270 dengan diameter $15,2 \mathrm{~mm}$.

\subsection{Analisa Pembebanan}

Aksi tetap yang terdiri dari :

- Beban mati

- Susut dan rangkak 
- Pengaruh prategang

Beban lalu lintas terdiri dari :

- Beban lajur "D"

- Beban truk "T"

Beban pejalan kaki

Faktor beban dinamis

\subsection{Menghitung Momen dan Perencanaan Tendon Prategang}

Perhitungan momen yang terjadi dengan bantuan software SAP 2000 akan menghasilkan momen dari hasil pembebanan dengan kombinasi pembebanan yang akan dipakai untuk menentukan jumlah tendon prategang.

\section{Hasil dan Pembahasan}

\subsection{Pembagian bentang (span) Jembatan}

Total panjang Jembatan Surabaya (THP Kenjeran) yang diremodeling menjadi box girder segmental adalah 192 meter, dibagi menjadi 4 bentang, dengan masing-masing bentang 48 meter.

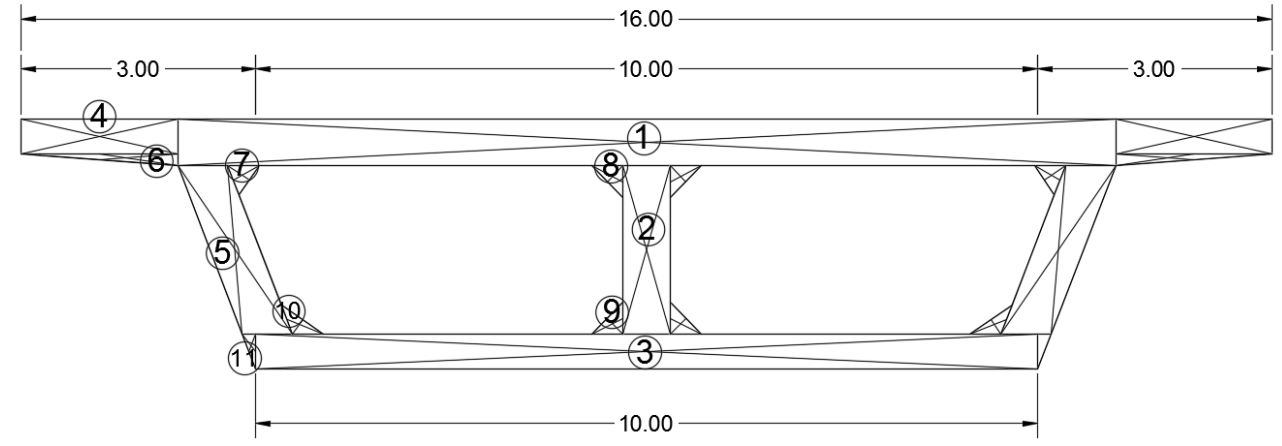

Gambar 3. Pembagian pias-pias dalam penampang box girder

\subsection{Perhitungan Titik Berat Box Girder}

Tabel 1. Perhitungan Letak Garis Berat (c.g.c) Box Girder

\begin{tabular}{|c|c|c|c|c|c|c|c|c|c|}
\hline $\begin{array}{l}\mathbf{N} \\
\mathbf{o}\end{array}$ & $\begin{array}{c}\text { Dimens } \\
i \\
\text { Lebar } \\
\end{array}$ & $\begin{array}{c}\text { Dimens } \\
i \\
\text { Tebal } \\
\end{array}$ & $\begin{array}{c}\text { Shape } \\
\text { Facto } \\
r\end{array}$ & $\begin{array}{c}\text { Jumlah } \\
\text { Penampan } \\
\text { g }\end{array}$ & $\begin{array}{c}\text { Luas } \\
\text { Penampan } \\
\text { g }\end{array}$ & $\begin{array}{l}\text { Jarak } \\
\text { thd } y\end{array}$ & $\begin{array}{c}\text { Statis } \\
\text { Momen }\end{array}$ & $\begin{array}{c}\mathrm{Yb} \\
(\mathrm{cm})\end{array}$ & $\begin{array}{c}Y a \\
(\mathrm{~cm})\end{array}$ \\
\hline 1 & 1200 & 60 & 1 & 1 & 72000 & 290 & $\begin{array}{r}2088000 \\
0\end{array}$ & $\begin{array}{r}189.7 \\
5\end{array}$ & $\begin{array}{r}130.24 \\
8\end{array}$ \\
\hline 2 & 215 & 60 & 1 & 1 & 12900 & 152.5 & 1967250 & & \\
\hline 3 & 1000 & 45 & 1 & 1 & 45000 & 22.5 & 1012500 & & \\
\hline 4 & 200 & 45 & 1 & 2 & 18000 & 297.5 & 5355000 & & \\
\hline 5 & 230.35 & 60 & 1 & 2 & 27642 & 152.5 & 4215405 & & \\
\hline 6 & 200 & 15 & 0.5 & 2 & 3000 & 270 & 810000 & & \\
\hline 7 & 40 & 40 & 0.5 & 2 & 1600 & $\begin{array}{r}247.5 \\
6\end{array}$ & 396096 & & \\
\hline 8 & 40 & 40 & 0.5 & 2 & 1600 & $\begin{array}{r}247.5 \\
6\end{array}$ & 396096 & & \\
\hline 9 & 40 & 40 & 0.5 & 2 & 1600 & 58.33 & 93328 & & \\
\hline 10 & 40 & 40 & 0.5 & 2 & 1600 & 57.44 & 91904 & & \\
\hline 11 & 45 & 17.31 & 0.5 & 2 & 778.95 & 30 & 23368.5 & & \\
\hline
\end{tabular}




\begin{tabular}{rrrrrrrr}
1 & 1200 & 60 & 1 & 1 & 72000 & 290 & 2088000 \\
2 & 215 & 60 & 1 & 1 & 12900 & 152.5 & 1967250 \\
3 & 1000 & 45 & 1 & 1 & 45000 & 22.5 & 1012500 \\
4 & 200 & 45 & 1 & 2 & 18000 & 297.5 & 5355000 \\
\hline
\end{tabular}

\subsection{Perhitungan Tegangan Ijin Bahan}

\subsubsection{Beton Prategang}

Berdasarkan SNI 1725-2016 kuat tekan beton yang direncanakan pada umur saat dilakukan penyaluran prategang atau pada saat transfer (fcr), dinyatakan dalam satuan MPa.

Tegangan ijin beton sesaat setelah penyaluran prategang (sebelum kehilangan prategang) :

Tegangan serat terjauh dalam kondisi tekan

Tegangan serat terjauh dalam kondisi Tarik

$$
\sigma_{\text {tekan }}=0,6 x \mathrm{fc}^{\prime}=0,6 \times 60=36 \mathrm{MPa}
$$

$$
\sigma_{\text {tarik }}=0,5 x \sqrt{f c^{\prime}}=0,5 x \sqrt{60}=3,87 \mathrm{MPa}
$$

Tegangan ijin beton pada saat beban layan :

Tegangan serat terjauh dalam kondisi tekan

$$
\sigma_{\text {tekan }}=0,45 x \mathrm{fc}^{\prime}=0,45 \times 60=27 \mathrm{MPa}
$$

Tegangan serat terjauh dalam kondisi tarik

Modulus Elastisitas Beton (Ec)

$$
\sigma_{\text {tarik }}=0,5 x \mathrm{fc}^{\prime}=0,5 \times 60=30 \mathrm{MPa}
$$

$$
E=4700 x \sqrt{f c^{\prime}}=4700 x \sqrt{60}=3,641 \times 10^{4} M P \alpha
$$

\subsubsection{Baja Prategang}

Berdasarkan SNI 1725-2016 tegangan ijin baja prategang terbagi dalam dua kondisi yaitu pada saat penarikan dan pada saat transfer gaya dan pengangkuran.

Modulus Elastisitas Baja (Es) $\quad=195.000 \mathrm{MPa}$

Tegangan Putus Kabel (fpk) $\quad=1860 \mathrm{MPa}$

Tegangan leleh kabel (fpy) :

$$
f_{p y}=0,85 x f_{p k}=0,85 \times 1860=1581 \mathrm{MPa}
$$

4. Tegangan tarik ijin kabel (jacking) :

$$
\sigma_{\text {jacking }}=0,94 x f_{p y}=0,85 \times 1581=1486,14 \mathrm{MPa}
$$

5. Tegangan tarik ijin kabel (setelah beban layan dan pengankuran) :

$$
\sigma_{\text {service }}=0,7 x f_{p y}=0,7 \times 1860=1106,7 \mathrm{MPa}
$$

\subsection{Perencanaan Tendon Prategang}

Untuk struktur bangunan atas (box girder), kombinasi yang digunakan berfungsi untuk menentukan tendon prategang dan tulangan box girder. Dari perhitungan momen dan kombinasi pembebanan diatas, didapatkan nilai momen untuk box girder sebesar $228.331 \mathrm{kNm}$.

Mengacu pada SNI 1725-2016, sesaat setelah transfer gaya prategang, boleh diambil sebesar 0,94 fpy dan tidak boleh lebih besar dari 0,80 fpu berdasarkan rumus $2.24-2.27$

$$
\begin{gathered}
F_{p k}=\frac{\text { Min.breaking load }}{A s_{\text {tendon }}} \\
=\frac{260.700}{140}=1862,143 \mathrm{MPa} \\
F_{p y}=0,85 \times F_{p k} \quad=0,85 \times 1862,143=1582,821 \mathrm{MPa} \\
\text { Batas leleh }=0,94 \times F_{p y}=0,94 \times 1582,821=1487,852 \mathrm{MPa} \\
\text { Batas putus }=0,8 \times F_{p k}=0,8 \times 1862,143=1489,714 \mathrm{MPa}
\end{gathered}
$$


Diambil nilai terkeil, sehingga didapat nilai Fpu (tegangan ijin tarik sesaat setelah transfer) sebesar $1487,852 \mathrm{MPa}$.

Data penampang box girder :

$$
\begin{aligned}
\mathrm{H} & =3200 \mathrm{~mm} \\
\mathrm{~A} & =1,857 \times 107 \mathrm{~mm} \\
\mathrm{yb} & =1897,52 \mathrm{~mm} \\
\mathrm{ya} & =1302,479 \mathrm{~mm} \\
\mathrm{I} & =2,339 \times 1013 \mathrm{~mm} 4 \\
\mathrm{Mu} & =2,283 \times 1011 \mathrm{Nmm} \\
\mathrm{wa} & =1,796 \times 1010 \mathrm{~mm} 3 \\
\mathrm{~kb} & =967,047 \mathrm{~mm} \\
\mathrm{wb} & =1,233 \times 1010 \mathrm{~mm} 3 \\
\mathrm{ka} & =663,792 \mathrm{~mm}
\end{aligned}
$$

Eksenstrisitas gaya prategang terhadap c.g.c :

Direncanakan tebal decking $200 \mathrm{~mm}$ :

$$
\begin{aligned}
& e=y b-\text { decking }=1897,52-200=1697,52 \mathrm{~mm} \\
& F_{O}=\frac{M u}{0,75 \times \text { H.box }}=9,2512 \times 10^{7} \mathrm{~N}
\end{aligned}
$$

Untuk sistem post tension diperkirakan terjadi kehilangan gaya prategang sebesar $20 \%$, maka Feff' :

$$
F_{\text {eff }}=\frac{F_{O}}{0.8}=1,189 \times 10^{8} \mathrm{~N}
$$

Perhitungan jumlah tendon pada kondisi beban layan (kombinasi pembebanan maksimum) adalah sebagai berikut :

Luas nominal strand yang diperlukan

$$
A_{p s}=\frac{\left(\frac{F_{\text {eff }}}{2}\right)}{F p u}
$$

$$
=\frac{\left(\frac{1,189 \times 10^{8}}{2}\right)}{1487,852}=3,996 \times 10^{4} \mathrm{~mm}^{2}
$$

Jumlah luas strand yang diperlukan dibagi dengan luas nominal satu strand.

$$
n=\frac{A_{p s}}{A s}=285,393 \text { ( jumlah strand yang dibutuhkan) }
$$

Jumlah tendon direncanakan dengan 22 strand tiap tendon (disesuaikan dengan tabel VSL yang ada) :

$$
\begin{aligned}
& \frac{n}{22}=12,972 \text { tendon } \sim 18 \text { tendon } \\
& 22 \times 18=396>n=285.393
\end{aligned}
$$

Maka digunakan tendon berjumlah 18 dengan masing-masing memiliki 22 strand.

Beban satu tendon :

Momen nominal yang dapat dipikul penampang

$$
P_{b s 2}=\frac{\text { Feff }}{n}=6,606 \times 10^{6} \mathrm{~N}
$$

$$
M n=\frac{M u}{0,8}=2,854 \times 10^{11} \mathrm{Nmm}
$$

Kontrol tegangan pada saat beban layan berdasarkan rumus $2.32-2.33$

Serat bawah

$$
\begin{aligned}
& f o_{1}=\frac{F_{\text {eff }}}{A c}+\frac{F_{\text {eff }} \times \text { e } \times y b}{I c}-\frac{M n \times y b}{I c} \\
& =\frac{1,189 \times 10^{8}}{1,857 \times 10^{7}}+\frac{1,189 \times 10^{8} \times 1697,52 \times 1897,52}{2,339 \times 10^{11}}-\frac{2,854 \times 10^{11} \times 1897,52}{2,339 \times 10^{11}}=1,752 M P a<\sigma_{\text {tarik }}
\end{aligned}
$$

$\underline{\text { Serat atas }}$ 


$$
\begin{aligned}
& f o_{2}=\frac{F_{\text {eff }}}{A c}-\frac{F_{\text {eff }} \times \text { e } \times y a}{I c}+\frac{M n \times y a}{I c} \\
& =\frac{1,551 \times 10^{8}}{1,857 \times 10^{7}}+\frac{1,551 \times 10^{8} \times 1697,52 \times 1302,48}{2,339 \times 10^{11}}+\frac{2,854 \times 10^{11} \times 1302,48}{2,339 \times 10^{11}}=13,179 \mathrm{MPa} \\
& \quad<\sigma_{\text {tekan }}=36 \mathrm{MPa}
\end{aligned}
$$

Dari hasil perhitungan diatas didapatkan batas atas perletakan tendon (pada daerah tumpuan) adalah $2561 \mathrm{~mm}$ dari serat bawah, sedangkan batas bawah perletakan tendon (pada daerah lapangan) adalah $642 \mathrm{~mm}$ dari serat bawah.

Mengacu pada batas atas dan batas bawah yang sudah ditentukan sebelumnya, jadi pada perencanaan ini titik awal tendon (pada daerah tumpuan) di titik $2500 \mathrm{~mm}$ (ULC, upper limit cable), dan pada tengah bentang (daerah lapangan) di titik $700 \mathrm{~mm}$ (LLC, lower limit cable).

Berikut gambar perletakan tendon pada tengah bentang dan tumpuan jembatan.

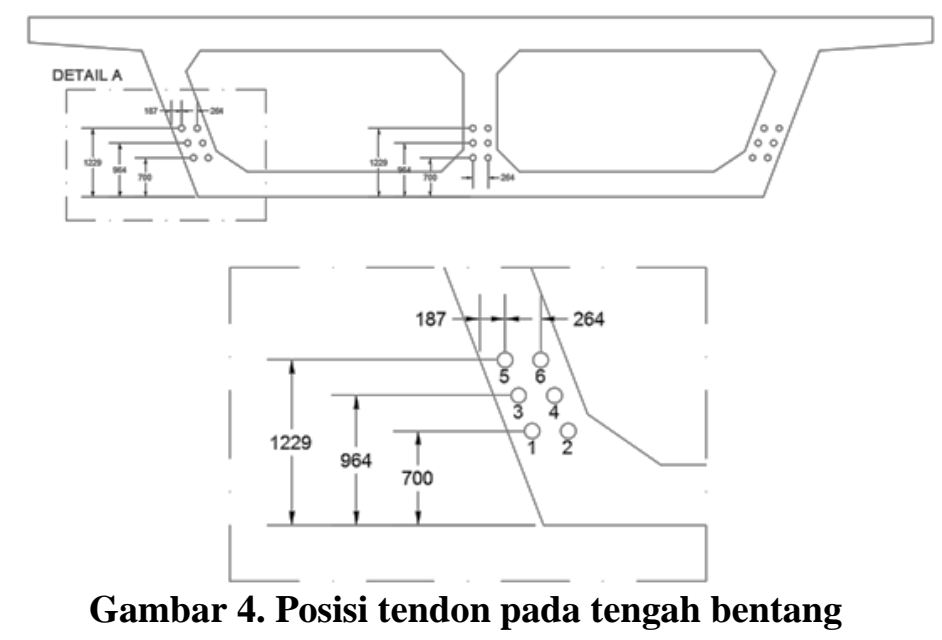

\section{Kesimpulan}

Kesimpulan dari Penelitian ini adalah : Dimensi box girder yang didapatkan dari hasil preliminary design jembatan dengan cara mencari tinggi taksiran box girder yaitu $1 / 15 \times \mathrm{L}$ dan menghasilkan tinggi box girder 3,2 meter, tipe yang digunakan adalah tipe houston ship channel dengan constant depth atau tinggi yang konstan. Kategori profil atau dimensi box girder pada perencanaan ini memenuhi apabila rasio penampang $0,45<0,51<0,55$. Gaya - gaya yang bekerja pada jembatan di kalkulasi ke dalam software SAP 2000 untuk mendapatkan momen - momen dengan masing - masing kombinasi pembebanan, sehingga dapat merencanakan kebutuhan tendon prategang dan tulangan-tulangan pada struktur beton. Tata letak tendon prategang ditentukan dengan hasil momen dari kombinasi pembebanan Service 1D, sehingga mendapatkan cable limit region berupa batas atas dan batas bawah posisi tendon prategang.

\section{Referensi}

[1] M. Fauzan, F. T. Pertanian, and J. B. Indonesia, "Analisis Struktur Box Girder Jembatan Fly Over Rawa Buaya Sisi Barat Terhadap Gempa," J. Tek. Sipil dan Lingkung., vol. 1, no. 1, pp. 42-56, 2016.

[2] I. Sebastian and F. X. Supartono, "Analisis Struktur Jembatan Gantung Self-Anchored," JMTS J. Mitra Tek. Sipil, vol. 2, no. 1, p. 169, 2019, doi: 10.24912/jmts.v2i1.3422.

[3] W. Nugraha and R. Chairulloh, "Analisis Metode Pengangkatan Gelagar Boks Baja Modular Untuk Jembatan Lintas Atas Sungai ( Ereksi Method Analysis of Modular Steel Box Girder for Bridge Over the River )," Tek. Sipil dan Perenc., vol. 2, no. 2, pp. 84-98, 2018. 
[4] P. Bujnakova, "Construction of precast segmental box girder bridge," IOP Conf. Ser. Mater. Sci. Eng., vol. 385, no. 1, 2018, doi: 10.1088/1757-899X/385/1/012007.

[5] K. E. C. Tanah and J. Aye, "Jurnal sipil sains terapan volume 02 nomor 01 21," vol. 02, pp. $21-$ $27,2017$. 